\title{
GENERAL CONTEXT OF CARRIER OBLIGATIONS IN CONTRACTS OF CARRIAGE OF GOODS BY SEA - REFERENCE TO SPANISH AND COLOMBIAN LAW*
}

\section{CONTEXTO GENERAL DE LAS OBLIGACIONES EN LOS CONTRATOS DE TRANSPORTE MARÍTIMO DE MERCANCÍAS - REFERENCIA A LOS DERECHOS ESPAÑOL Y COLOMBIANO}

\author{
Fernando Jiménez-Valderrama** \\ Reception date: May 12 $2^{\text {th }}, 2015$ \\ Acceptance date: September $24^{\text {th }}, 2015$ \\ Available online: November $30^{\text {th }}, 2015$
}

\section{To cite this article/Para citar este artículo}

Jiménez-Valderrama, Fernando, General Context of Carrier Obligations in Contracts of Carriage of Goods by Sea - Reference to Spanish and Colombian Law, 131 Vniversitas, 363-390 (2015). http://dx.doi.org/10.11144/ Javeriana.vj131.gcco doi:10.11144/Javeriana.vj131.gcco

* This article was written on the research project Transformaciones del ordenamiento jurídico colombiano a partir de la vigencia de los Tratados de Libre Comercio con los Estados Unidos y la Unión Europea, University of La Sabana, Colombia.

** PhD, University of Salamanca (Spain). LLM, European Union Law University of Carlos III (Spain). Professor and Head of Private and Business Law Department, University of La Sabana, School of Law, Bogotá, Colombia. Contact: fernando.jimenez@unisabana.edu.co 


\section{ABSTRACT}

The regulation of carriage of goods by sea contracts has evolved from a system of absolute freedom of agreements towards a limitation of freedom of the parties. Legislation in Spain and Colombia follows this evolution to international legislation (The Hague Visby Rules, The Hamburg Rules and the recent Rotterdam Rules). Spanish Shipping Act 2014 and some rules in Colombian Commercial Code show this trend. Under the current legislation in Spain and Colombia, the whole carriage of goods by sea contracts are built over the transport obligation, as the main commitment in the contract, even in affreightment (Spanish Shipping Act 2014).

Keywords: obligations in carriage of goods by sea contracts; affreightment; Shipping Act 2014; Colombian Maritime Law; the Hague Visby Rules; the Hamburg Rules; the Rotterdam Rules 


\section{RESUMEN}

La regulación de los contratos de transporte marítimo de mercancías ha evolucionado desde un sistema de absoluta libertad hacia una limitación de la libertad de las partes contractuales. La legislación en España y Colombia ha seguido esta evolución con una perspectiva internacional (Reglas de La Haya - Visby, Reglas de Hamburgo y las recientes Reglas de Rotterdam). En España, la Ley de Navegación Marítima de 2014 y algunas normas del Código de Comercio colombiano muestran esta tendencia. Bajo la legislación actual en España y en Colombia, todas las formas contractuales de transporte marítimo se han construido sobre el resultado de transporte, como la más importante prestación en estos tipos de contratos, aun en los esquemas fletamentarios (como en el caso de la legislación española).

Palabras claves: obligaciones en el contrato de transporte marítimo de mercancías; ley de navegación marítima 2014; derecho marítimo colombiano; reglas de La Haya Visby; Reglas de Hamburgo; Reglas de Rotterdam

\section{SUMMARY}

INTRODUCTION.- I. LAW GOVERNING THE CARRIAGE OF GOODS BY SEA CONTRACT.- II. Spanish and Colombian legislation of CARriage of GOOdS BY SEA.- A. Consecration of a Device Law.- B. Subsidiary nature.- C. The ship-owner holds a privileged position in the conclusion, execution and possible liability for breach of contract, against the cargo owner party.- III. The Hague-Visby Rules and Spanish Shipping Act 2014.- IV. Carrier's obligations in the Spanish Shipping Act 2014.- $A$. The influence of the Anglo-Saxon System.- B. The influence of "modern lex mercatoria".- $C$. The Hague - Visby Rules is an instrument for regulating carrier.- D. The affreightment as the contract that regulates carriage of goods by sea in the Spanish Shipping Act 2014.- V. The OBLIGATION OF TRANSPORT AS THE CORE OF CARRIAGE OF GOODS BY SEA CONTRACT.- VI. THE TRANSPORT OBLIGATION AS PRIME ISSUE IN THE CARRIAGE OF GOODS BY SEA CONTRACT UNDER THE COMParative LAW.- Conclusions.- Bibliography. 


\section{INTRODUCTION}

The plurality of regulatory normative sources in carriage of goods contracts, some coming from national and others from international sources, ${ }^{1}$ make the treatment of this type of contract a complex matter.

Being mainly an international economic activity, a confluence of legal systems from different legal families is inevitable (in Western world case, systems that belong to the so called common law and systems link to the so-called European continental law).

In this article we study the general structure of the obligations that arise in contracts of carriage of goods by sea, in order to establish a coherent set of principles applicable to Spanish and Colombian law.

\section{LAW GOVERING THE CARRIAGE OF GOODS BY SEA CONTRACT}

Currently, regulations in force in Spain, regulating carriage of goods by sea, are contained in the Shipping Act 2014 and the Hague-Visby Rules, ${ }^{2}$ introduced into domestic law through the

1 In Spain, the Shipping Act 2014 and in Colombia, the Colombian Commercial Code. Internationally, we mean successive conventions that have governed the matter, particularly the so-called The Hague-Visby Rules, the Hamburg Rules and the Rotterdam Rules recently adopted. Spain, Shipping Law, Ley 14/2014, navegación marítima, 24 de julio de 2014, 180 Boletín Oficial del Estado, BOE, 25 de julio de 2014, 59193-59311. Available at: http://www. boe.es/diario_boe/txt.php?id=BOE-A-2014-7877. Colombia, Decree 410 of 1971 (March 27), by which the Commercial Code is enacted Commercial Code. Available at: http://www. secretariasenado.gov.co/senado/basedoc/codigo_comercio.html. The Hague-Visby Rules. Available at: http://www.admiraltylaw.com/statutes/hague.php. United Nations Commission on International Trade Law, UNCITRAL, United Nations Convention on the Carriage of Goods by Sea (Hamburg, 1978) Hamburg Rules. Available at: http://www.uncitral.org/uncitral/ en/uncitral_texts/transport_goods/Hamburg_rules.html, http://daccess-dds-ny.un.org/doc/ UNDOC/GEN/N94/057/28/PDF/N9405728.pdf?OpenElement. United Nations Commission on International Trade Law, UNCITRAL, United Nations Convention on Contracts for the International Carriage of Goods Wholly or Partly by Sea (New York, 2008) Rotterdam Rules. Available at: http://www.uncitral.org/uncitral/en/uncitral_texts/transport_goods/2008rotterdam_rules.html

2 When we call the international regulations on maritime transport and the Hague-Visby Rules, we refer to the Brussels Convention of 1924, as amended by the Protocols of February 23, 1968 (Rules of Visby) and December 21, 1979. Protocol (SDR Protocol) amending the International Convention for the Unification of Certain Rules of Law relating to Bills of Lading of 25 August 1924 (The Hague Rules), as amended by the Protocol of 23 February 1968 (Visby Rules) (Brussels, 21 December 1979). Available at: http://www.admiraltylawguide.com/conven/ sdrprotocol1979.html. Protocol (SDR Protocol) amending the International Convention for the Unification of Certain Rules of Law relating to Bills of Lading of 25 August 1924 (The 
Shipping Act 2014, considering aspects reformed by the Protocols of February 23, 1968, and December 21, 1979, amendatory of the Brussels Convention 1924. ${ }^{3}$

Although, Colombia has not ratified any of these international agreements, leaving the Commercial Code as the only existing domestic legislation; in practice, the international carriers often regulate their business relationships using the above-referred conventions, considering the power of the parties to establish the legal framework to regulate their relationship. ${ }^{4}$

If we consider that the aforementioned rules currently remain in force, the first point to consider is their coordination and integration when regulating the carriage of goods by sea. On a general level, we can derive that the existence of a dual system is by no means exclusive, although complementary.

Legal relationships regulated by the Hague-Visby Rules are subject to its provisions imperatively; the parties can regulate matters

Hague Rules), as amended by the Protocol of 23 February 1968 (Visby Rules) (Brussels, 21 December 1979). Available at: http://www.admiraltylawguide.com/conven/sdrprotocol1979. $\mathrm{html}$. As we know, the Brussels Convention of 1924, which regulates international standard carrying of goods with bills of lading, was ratified by Spain on June 2, 1930 (212 Gazette of Madrid of July 31,1930). The same Convention provides the text of the incorporation process into national legislation: "The High Contracting Parties may give effect to this Convention, and giving it the force of law, and introducing into their national legislation the rules adopted by the Convention appropriately to this legislation." The Spanish government not only ratified the Convention but rather incorporated it into domestic law by an Act (Shipping Act 2014). Later Protocols amending the Brussels Convention of 1968 and 1979 were also ratified by Spain (Spain, Instrumento de Ratificación de 16 de noviembre de 1981, del Protocolo de 21 de diciembre de 1979, que modifica el Convenio Internacional para la unificación de ciertas reglas en materia de conocimientos de embarque de 25 de agosto de 1924 (Gaceta de Madrid, 31 de julio de 1930), enmendado por el Protocolo de 23 de febrero de 1968, 36 Boletín Oficial del Estado, BOE, 11 de febrero de 1984, 3674-3677. Available at: http://www.boe.es/diario_boe/txt. php?id=BOE-A-1984-3645), although not incorporated by law. Although with no legal enactment, which reproduce these protocols, these numbers can be considered current via Article 961 of the Spanish Constitution. Thus, we can conclude that currently existing regulations in Spain on transport of goods by Sea under the bill of lading is made by the Shipping Act 2014, which incorporates the Brussels Convention, partially amended by the 1968 and 1979 Protocols.

3 While Spain ratified on January 19, 2011 the United Nations Convention on Contracts for the International Carriage of Goods Wholly or Partly by Sea (Rotterdam Rules 2008), this legislation is not yet in force since the Convention requires the ratification by at least 20 countries. So far, only three countries have ratified the Convention (Spain, Togo, and Congo).

4 We must also note the legal sources system of Colombian recognize international treaties or conventions not ratified by Colombia, the international commercial practice which meets the conditions of Article 3 of the Code of Commerce, as well as the general principles of commercial law. All these rules may be applicable when under Article 7 of this code if "cannot be resolved in accordance with the preceding rules" (these are set out in Articles 1 to 6 of the encoded rules). 
not specifically addressed by the law imposed on the contractors. Meanwhile, the Spanish Shipping Act 2014 comes into play to regulate situations in which there is no special peremptory norm, or no express will of the parties on a particular point. ${ }^{5}$

In Colombia, there is no special law regulating the matter as there is in Spain. Therefore, the rules laid down in the Commercial Code apply to relations of carrying goods by sea. In general, the aim of the Colombian Code, like their counterparts in the Roman law, is essentially a substitute for contractual will, but we need to say that although a general rule, there are some points where the Colombian Commercial Code (Article 4) states its imperative character. ${ }^{6}$

\section{SPANISH AND COLOMBIAN LEGISLATION OF CARRIAGE OF GOODS BY SEA}

Rules contained in the Spanish legal tradition come from Commercial Code rules. Rules in $19^{\text {th }}$ century correspond to a different historical moment and, therefore, different needs and interests. Undoubtedly, the economic environment surrounding the shipping industry in the $19^{\text {th }}$ century was substantially different from the situation that the same activity has today. The difference between two situations lies not only in the level of technological development of navigation, but has deeper implications rooted in relations of economic power and the weight of the maritime legal tradition prevailing in every age. In the field of technological advances,

5 The rules governing this issue in the Spanish Shipping Act 2014, which in turn have an antecedent in the rules established by the Commercial Code of 1885 , were prepared in a historical moment in which the different types of contract through which the carriage of goods is done were not distinguished. Therefore, when applying, this fact should be borne in mind in order to interpret the transport as an essential element of the affreightment institution.

6 Article 994 Colombian Commercial Code states that "When government required, the carrier must take on its own account or on behalf of the passenger or cargo owner, an insurance policy covering people and objects transported from the risks inherent to the transport. The carrier cannot become its own risk or liability insurer. The government shall regulate the requirements, conditions, and amounts of insurance protections provided in this article, which will be given by insurance companies, cooperative insurance, legally established." Similarly, the rules provided for in Article 1031 Colombian Commercial Code on compensation for total or partial loss of the goods are mandatory in nature; also Articles 1612 and 1618 of the Colombian Commercial Code prevent modification of the rules governing the exemption and limitation of liability of the carrier to transport things in general, except in the case of increasing responsibility (art. 1612), or no assumptions regarding the liability for weight, quantity, number, identity, nature, quality, and condition of the goods when received (art. 1618). 
clearly the gap between both regulations can be observed: while the regulation in the Commercial Codes was created to deal with underdeveloped navigation, based on sailing, existing legal institutions must regulate a new reality in which there is a breakthrough in navigation techniques that enable celerity, regularity, and safety in sea crossing. ${ }^{\text {? }}$

Simultaneously to the technological facts, the power relations that arose in the 19th century were different from todays. The system adopted by the Commercial Code was based on respect for the principle of private autonomy in determining the legal embodiment of the transport activity, enabling the introduction by the sea carrier of provisions favorable to their interests that reduced or even eliminated responsibility. If to this recognition we add the effect of derogating measures favorable to the ship owner (as set forth on the limitation of liability of the ship owner by the abandon ship and freight system), we can understand its preeminent position in the celebration and execution of the contract of carriage of goods against the cargo owner part.

The Colombian Commercial Code, although recently approved, has significant matches to the Spanish regulations. Both laws are the result of a coding process that aims to regulate commercial activity under the principles of free enterprise and respect for private autonomy, which inspired the entire encoder movement from the mid-eighteenth century.

We could say that both, the Colombian and Spanish Shipping Act 2014, by regulating the first one the contract of carriage of goods by sea and, the second one, the affreightment, have the following characteristics:

\section{A. Consecration of a Device Law}

The issuance of shipping norms is done in a spirit of respect for the principle of freedom of contract, which is the foundation of all private law. Under this principle, the parties were legally authorized to establish the conditions deemed appropriate in regulating economic relations, giving the legal system a subsidiary role to the

7 Pierre Bonassies, Le droit du transport maritime de conteneurs à l'orée du 21 e siècle, 699 Droit Maritime Français, 7-15, 7 (2009). 
private autonomy. The limits imposed by law (law, morality, and public order) attached great extent to the development of freedom of contract, according to the economic needs of the time, in which capitalist institutions were consolidated in the economic structure.

Although this principle remains the central pillar of private law, the situation is different as the development of the capitalist economy has required the establishment of a greater number of limits to the private sector in order to direct it towards the correction of possible harmful consequences that a system of extreme liberalism would lead towards society.

With respect to maritime law, this trend towards limiting the exercise of autonomy of private will can be clearly seen if the rules established in the commercial codes (largely permissive in recognizing the agreements made by the parties) are contrasted against subsequent regulations. Such is the case of the Brussels Convention of 1924, the Hamburg Rules 1978, and the Rotterdam Rules 2008, which lay down a mandatory scheme that must be respected by the parties holding private covenants.

Alongside the continental European Commercial Codes, at the comparative law level, a similar contrast can be distinguished between the rules that traditionally regulated the carriage of goods by sea. For example, the internal rules of common law, and new regulations normally contained in special laws that provide compulsory laws which usually comes from international conventions. Thus, while the common law widely recognized agreements made by the parties, the British Shipping Act (Carriage of Goods by Sea Act 1971) provides for the mandatory regime of the Brussels Convention $1924 .{ }^{8}$ Similarly, in French law the same evolution can be distinguished between the French Commercial Code and the first French Carriage of Goods by Sea Act April 2, 1936 and today's current 66-420 Act of June 18, 1966.

8 Robert Samuel Theodore Chorley, Otto Charles Giles \& Nicholas J. Gaskell, Shipping Law, 169 (Pitman, London, 1992). Thomas Gilbert Carver \& Raoul Colinvaux, Carver's Carriage by Sea, 294 (13 ${ }^{\text {rd }}$ ed., Stevens \& Sons, London, 1982). Thomas Edward Scrutton, Michael J. Mustill, Stewart Crauford Boyd \& Alan Abraham Mocatta, Scrutton on Charterparties and Bills of Lading ( $19^{\text {th }}$ ed., Sir Alan Abraham Mocatta, Michael J. Mustill \& Stewart C. Boyd, eds. Sweet \& Maxwell, London, 1984). 


\section{B. Subsidiary nature}

The subsidiary nature of the Code of Commerce rules, as well as those of Shipping Act 2014, is a result of the acceptance of the principle of freedom of contract. Clearly, the law recognized importance to private autonomy as a generator of rules binding on the parties; thus, rules established in the law fulfill a purely subsidiary role, i.e. compliance is seen contingent on the absence of regulation expressed by the contractors. Subsidiarity of the rules encoded contrasts sharply with the rules in force today in the same content, established by a regulation with a marked overriding trend. Today, the legislature, encouraged by the emergence of new circumstances, has decided to take an active part in the regulation of this economic activity. This trend has several causes, of which we will discuss only those we consider the most important: from the recognition of the principle of freedom of agreements, the stronger party in the relationship (carrier) imposes their interests on the weaker counterpart (cargo owner). In a situation of economic imbalance the law does not support the principle of uncompromising freedom of agreements, since this would lead in practice to validate agreements whose content differs from any sense of fairness or justice.

Moreover, as the maritime trade became widespread, there was a growing state interest in controlling this important economic sector. This, coupled with the growing process of uniformity of maritime law, identified the need for greater state intervention in regulating the carriage of goods, so that the subsidiary original regulation was replaced by systems with a clearly mandatory character. Specifically, in the area of the carrier's obligations in the contract of carriage of goods, the transition to mandatory forms had a significant impact. Respect for the autonomy of the parties in the establishment of own contractual provisions of the Shipping Act 2014 (originally of Commercial Code) was replaced by a regulation of mandatory character, establishing contract minimums that subjected the parties to hold regulatory legal business of carriage of goods. The Brussels Convention of 1924, as amended (protocols 1968 and 1979), the Hamburg Rules 1978 and the Rotterdam Rules 2008 are inserted in this line. 


\section{The ship-owner holds a privileged position in the conclusion, execution, and possible liability for breach of contract, against the cargo owner party}

The rules contained in the codified rules are the result of a long Mediterranean and Atlantic legal tradition that goes back many centuries. As a consequence, the Codes of Commerce held institutions created by the commercial usage, unsettled maritime business experience, and embodied in different laws (including Ordinances of Bilbao, 1737, the Book of the Consulate of the Sea and Barcelona Ordinances, 1258). All these regulations were created in a historical period in which the maritime business required huge capital because of navigation techniques and insecurity, which made the business subject to great risk. Therefore, the only way to balance a clearly unfavorable situation for the carrier was to establish a special system that will endow him a particularly privileged position that could not be given by the common law. The Code of Commerce rules, as well as the Shipping Act 2014, both recipients of this tradition, developed a special scheme giving favorable treatment to the carrier, especially because of the adverse circumstances in which operates (a clear example of this treatment is the recognition of the benefit of limitation responsibility by way of abandoning ship and freight recognized in Article 587 of the Spanish Commercial Code and Article 1737 of the Colombian Commercial Code).

\section{THE HAGUE-VISBY RULES AND SPANISH SHIPPING ACT 2014}

The conclusion and signing of the Brussels Convention of 1924 is part of a unifying tendency of international carriage by sea rules. Apart from this purpose, mainly driven by the international nature of this economic activity, there were specific interests of different economic operators to reach an agreement in order to change a situation that clearly was inconvenient for the market development of modern shipping. The embodiment in the national legal system established a rigid regime of responsibility, which in practice looked continually circumvented by contractual clauses limiting liability. The first rule that reacted to this situation was the American Harter 
Act, 1893, issued by a country with clear cargo interests that unilaterally decided to establish a particular tax provision to related parties in the shipping contract. Subsequently, the conclusion and signing of the Brussels Convention of 1924, was another step in the evolution towards greater modernization of international regulation, and specifically to a better balance of the parties involved.

\section{CARRIER'S OBLIGATIONS IN THE SPANISH SHIPPING ACT 2014}

As mentioned before, the succession of laws of carriage of goods has not only been a necessary process of regulation updating but also the establishment of a new orientation in a transition, from a dispositive system to a mandatory one that regulates the transportation relationships.

There are other important features that must be taken into account when establishing the system of obligations in the contract of carriage of goods:

\section{A. The influence of the Anglo-Saxon system}

The direct antecedent of the system established by the Brussels Convention of 1924 is an U.S. regulation passed in 1893 known as the Harter Act. This rule was filed in the United States per initiative of the cargo sector. Through its regulation, the intention was to balance the economic benefits of the contract of carriage of goods by sea which, due to the freedom of contractual arrangements, were very favorable to the usually more powerful party in the contractual relationship (the carrier).

The enactment of the Harter Act marked a success milestone to the movement to reform the current legislation. His example was followed by other shipper countries, to the point that began to interest others traditionally carrier countries, who saw in its rules a chance to access a desirable unification of maritime rules. This was the ambience in which the Brussels Convention of 1924 was signed.

As an international agreement, the Brussels Convention of 1924 and its amending protocols (known as the Hague-Visby Rules) 
attempted to reconcile the regulation of the carriage of goods by sea of the two major Western legal families (Anglo-American Common Law and Continental European Law), but with a markedly Anglo outcome. It was obvious that during the $19^{\text {th }}$ and early $20^{\text {th }}$ centuries, the UK wielded a leading position worldwide due to its economic development and use of maritime trade routes, which resulted in an influence of English legal institutions in governing the matters. On the other hand, it is clearly recognizable that the International Maritime Committee was formed by domestic-private partnerships in which almost certainly the interests (mainly English) of the ship-owners associations prevailed. ${ }^{9}$ It is therefore understandable that the regulation, as the Brussels Convention of 1924, which was the result of a Diplomatic Conference arranged by the International Maritime Committee, respected the English model of regulation of contracts of carriage of goods.

With the subsequent Spanish ratification of the Convention, and its enactment into law, the Spanish legislature had the opportunity to change the overall design of these rules in the form of adapting them to the continental European model in force in Spain, while always respecting their content. However, the Shipping Act 2014 was limited to introduce the Hague-Visby rules as the law applicable to bills of lading contracts (art. 277.2).

The application of the Spanish Shipping Act, therefore, requires some special considerations. The fact that its origin is linked to an international convention with a clear unifying purpose provides us an orientation on which we must interpret the rule in question. This interpretive principle has been used in decisions issued by judges from other countries, and we believe it is applicable to the Spanish case and other systems of continental European family, as in the case of Colombian law. ${ }^{10}$

9 Georges Ripert, Droit Maritime, 779 (Librairie Arthur Rousseau et Compagnie Éditeurs, Paris, 1929).

10 This principle is known internationally as the "beginning of history" and was enunciated by Judge MacMillan in the case Stag Line Ltd. v. Foscolo, Mango \& Co. Ltd. [(1932), 41 Lloyd's 165 at 174], as follows: "It should be noted that the 1924 Convention was the result of an international conference and that the rules are internationally applicable. If rules are taken into account in foreign courts, it is important that in the interest of uniformity, their interpretation is not rigidly controlled by domestic precedents of an earlier date. The language of the rules should be based on general principles generally accepted." This principle has been taken into account in deciding different cases: in the case of Maxine Footwear Co. Ltd. v. Canadian Government Merchant Marine [(1959) AC 589], the British Privy Council used this 
The application of this principle requires consideration of the unifying purpose of the international standards of Hague-Visby, therefore, its practical application is not subject solely to the guidelines laid down by national law. Following this criterion, when we interpret bill of lading contracts, we can refer to the contents and developments that other countries gave to the Brussels Convention, and especially the Anglo contents, which served as a direct source for its creation.

\section{B. The influence of "modern lex mercatoria"}

In the development of the discipline of maritime law, the uses and customs of men dedicated to the sea have played a very important role. The legal texts produced during the late Middle Ages were intended to collect the customs that were being inveterately respected by operators of maritime activity. Through these customs, many of the usual maritime institutions that currently regulate the contract of carriage of goods were created.

From the origins of maritime law to this day, the influence of commercial customs has remained. Although law now has become the primary source of private legal structure, clearly showing a strong positivist trend, in maritime matters, the uses and importance of international customs has largely remained, reflected in the existence of different contractual forms used in practice to regulate shipping legal relations. ${ }^{11}$

principle to rule the doctrine of the stages (stages) in the obligation of seaworthiness. On the other hand, the Spanish doctrine has also accepted this interpretive principle. FranCISCO FARIÑa-Guitián, El transporte marítimo y sus sistemas de responsabilidad, 133 (Consejo Superior de Investigaciones Científicas, CSIC, Ministerio de Marina, Madrid, 1959). Fernando SÁnChez-CAlero, El contrato de transporte marítimo de mercancías, 51 (Consejo Superior de Investigaciones Científicas, CSIC, Madrid, 1957). Eduardo Polo-Sánchez, Alcance de la responsabilidad del fletante y del porteador por falta de navegabilidad inicial del buque, Revista Jurídica de Cataluña, RJC, 867-912, 869 (Sept.-Dec., 1969).

11 Routes of penetration of international custom in national legal systems are really close, as they are designed to recognize a "local" habit with relative ease in the evidentiary mechanisms, the present popularity of the law against any conflict with custom that is contrary (contra legem). Thus, the dynamics of international trade practice has led to the generation of rules preferably operating in the contractual level of autonomy dispositive of the parties, i.e., the individual rules, ex contractu and not sufficiently objectified to transcend the range of sources of law rules. Terms and Conditions in typical contracts are, if you will, a new technique in developing the content of the contract, ultimately in the formulation of the bargaining will. José María Gondra-Romero, La moderna "lex mercatoria" y la unificación del derecho del comercio internacional, 127 Revista de Derecho Mercantil, 7-38, 26 (1973). 
The proliferation of such forms has a practical explanation. First, the need for unification of different rules of maritime law; obviously, in absence of a positive unification, the maritime activity developed designed their own rules embodied in the contractual policies that, by virtue of widespread use, acquire the desirable uniformity in the legal regulation. Second, there was a fact that prevented the development of maritime trade in the range that currently requires the global economy. There was no denying the degree of mismatch that had the current legislation regarding the needs of a growing maritime trade. Given this fact, maritime operators, in order to meet their needs, attended private autonomy to regulate trade to their own needs. ${ }^{12}$

The proliferation of forms and contractual policies itself is not a problem, it is simply a manifestation of the dynamics presented by this economic activity, which really must be taken into account

12 Currently, we can check for the presence of a trend toward uniformity of commercial law at the international level, determined by the occurrence of various factors, both economic (economic globalization) and political (insertion of so-called developing countries in the under various international decision-making bodies). This aim has been claimed to be achievable through different legal techniques used by the different countries concerned and by the various economic operators that require a unified law giving security in developing their international business activities: Firstly, legal uniformity can be achieved through the establishment of a supranational law (as is the case of the European Union and the Andean Community of Nations) or through the conclusion of bilateral or multilateral agreements between countries. Although these mechanisms are the most desirable from the point of view of technical and legal clash with essential principles such as national sovereignty, impeding its generalization. Similarly, in the field of commercial practice, wide dissemination of standard contracts and general conditions of contract, made by those involved in international economic operations is presented. Based on the international recognition of the principle of autonomy, economic operators have designed their own right, independent of national rights, in what has been called doctrinally modern lex mercatoria (Schmitthoff, Gondra), paralleling this right with the created one by the mercantile corporations (ius mercatorum) during the late Middle Ages, in which the main source of trade law or custom applications constituted (usus mercatorum) were recognized by the traders themselves and applied in specialized courts. While we are facing a trend that spans the commercial system, this phenomenon is stronger and has developed more quickly, and dissemination materials for its distinctly international character set required creating a right to their own needs, such as the case of the shipping industry. José María Gondra-Romero, La moderna "lex mercatoria" y la unificación del derecho del comercio internacional, 127 Revista de Derecho Mercantil, 7-38, 7 (1973). Clive M. Sснмiтthoff, The Unification of the Law of International Trade, The Journal of Business Law, 105-119 (1968). RAFAel Illescas-ORTIZ, El derecho uniforme del comercio internacional: elementos de base, Estudios de Derecho Mercantil en homenaje al profesor Manuel Broseta-Pont, II, 1781-1800, 1782 (Tirant lo Blanch, Valencia, 1993). Aurelio Menéndez-Menéndez, El derecho mercantil en el siglo XXI, 4 La Ley: Revista Jurídica Española de Doctrina, Jurisprudencia y Bibliografía, 1196-1203, 1196 (1990). José Antonio Gómez-Segade, Algunos problemas actuales del Derecho Mercantil, en Estudios en homenaje a Rodrigo Uría, 209-227, 209 (Civitas, Madrid, 1978). 
when structuring the obligations arising from the conclusion of a contract of maritime carriage of goods.

\section{The Hague-Visby Rules is an instrument for regulating carrier liability}

The 1924 Brussels Convention is not intended to fully regulate the contract of carriage of goods, but its scope is limited only to the carrier's liability. However, regulating the carrier's liability requires affecting the obligational structure of the contract of carriage of goods, as it is shown in the third article of that international treaty.

Consequently, this direct reference to the rules of the Convention and the Spanish Shipping Act obligations of the carrier, as well as the indirect reference to the other rules governing the responsibility of the shipping institute, helps us as a reference when setting obligations arising from the contract of carriage of goods.

\section{The affreightment as the contract that regulates carriage of goods by sea in the Spanish Shipping Act 2014}

Finally, it is important to say that the Spanish legal tradition uses legislation to regulate the economic activity of carriage of goods by sea. ${ }^{13}$ This idea is important as it indicates the direction of the Spanish doctrine and jurisprudence about the legal nature of the affreightment. Following Spanish tradition the Shipping Act 2014 considers the affreightment as the carriage of goods by sea contract (art. 203)

13 Understanding the obligation to carry inserted in the charter contract governed by Spanish Commercial Code is due, among other reasons, to a prolonged evolution of these types of contracts, having one of its leading and oldest record in the institution pretoria the receptum nautarum. In reference to the content of such promise in the post-classical period refer to Patricio Ignacio Carvajal-Ramírez, La persistencia de recipere en su acepción de prometer y la desvinculación entre vis maior y la exception labeonis en época post-clasica: salvum recipere obligare y suscipere in fidem suam, en Studi in onore di Antonino Metro, 409-450, 409 (CARMELA Russo-Ruggeri, Giuffrè, Milano, 2009). 


\section{THE OBLIGATION OF TRANSPORT AS THE CORE OF CARRIAGE OF GOODS BY SEA CONTRACT}

The establishment of the obligation to move and deliver goods on arrival as a key provision within the structure of the contract of carriage of goods, is the fact that marks the distinction and origin of an autonomous contract from other figures such as affreightment and associated forms. Historically, this coincides with the evolution of the embodiments of shipping from associative types, in which there was participation of all members in the implementation of maritime transport, towards contractual forms in which one party assumes the obligation to move goods against another, namely, the payment of the price. ${ }^{14}$ Similarly, in the field of transport agreement documents, this change coincides with the replacement of the cartulario as a document evidencing the receipt of goods with the bill of lading. ${ }^{15}$ Furthermore, the obligation to carry as characterizing this contract was received and maintained by the Spanish legal tradition, unlike other jurisdictions, such as the French, in which the charter was considered as a lease ${ }^{16}$.

Not only considerations of historical and legal traditions lead us to understand the fundamental obligation of the carriage of goods by sea contract. The reality of the contracts backs this up: the economic aim pursued by the cargo owner to agree to the contract is the transfer of goods from one port to another and to receive them in the same condition as delivered. It, thus, seems logical that this

14 José Girón-Tena, El naviero: directrices actuales de su régimen jurídico, 9 (Universidad de Deusto, Bilbao, 1959). Antonio Brunetti, Derecho marítimo privado, 151 (Bosch, Barcelona, 1950). Manuel Peláez, Los contratos de fletamento en el derecho histórico catalán, 2 Anuario de Derecho Maritimo, 93-133, 107 (1982).

15 Jesús Rubio, El fletamento en el derecho español, 22 (Revista de Derecho Privado, Madrid, 1953).

16 Let's recall that in the French Ordinance of 1681 a very broad concept of chartering is set in Book III, Title I, Art. 1: "Toute convention pour louage d'un vaisseau, appelée chartepartie, affrètement ou nolissement..." doctrinally interpreted as a lease. JEAN-MARIE PARdEssus, Collection des lois maritimes antérieures au XVIII siècle, 358 (L'imprimerie royale, Paris, 1845). Available at: http://gallica.bnf.fr/ark:/12148/bpt6k109656h.r=collection+des+lois+maritimes. langFR, http://gallica.bnf.fr/ark:/12148/bpt6k109657w/f689.image. JEsús RuBio, El fletamento en el derecho español, 25 (Revista de Derecho Privado, Madrid, 1953). LÉon Robert MÉnAger, "Naulum" et "Receptum rem salvam fore". Contribution à l'étude de la responsabilité contractuelle dans les transports maritimes en droit romain, 38 Revue Historique de Droit Français et Étranger, 4, 177-213, 385-411, 182 (1960). 
economic fact shows the transport as the main aspect of the contract purpose. ${ }^{17}$

According to this, we must say that the first and essential benefit that arises to the shipping carrier or shipper refers to the transport of the goods received. ${ }^{18} 19$ Thus, the same happens with commercial transport contracts in general, with the execution of the legal transaction arises a fundamental obligation under which the carrier undertakes to transport the goods from the port of departure to the destination port, and within the agreed conditions, delivering them in the same condition they were received. This starting point, although it seems evident within the structure of other commercial contracts of carriage, it is not so in this legal concept, especially because of the wide doctrinal discussion that has occurred regarding the legal nature of utilization vessel contracts.

The system established by Spanish law can only be understood starting from the basis of an obligation to transport inclusive of the various benefits that are required by the carrier, which may include the duty to provide the seaworthiness of the vessel, the custody of the goods, and restitution made after transport to the port of destination.

Regarding Colombian law, we mentioned that the core of the contract of carriage of goods is located in the relevant rules of the Commercial Code. Article 981 of the Colombian Commercial Code makes clear the centrality of the obligation to carry by claiming

17 Although this is an essential concept in the analysis of the contract obligations, authors have preferred to avoid it, and go directly to the positive texts on its base, establish a responsibility system that reproduces the various duties that link the carrier in the legal relationship. A conceptualization of the matter would be avoided, which would be useful to have an overview of the contract, not subject to the casual effect of a given policy. Rafael Matilla-Alegre, Contrato de utilización del buque, Lecciones, 144 (Bosch, Barcelona, 1988). Fernando Sánchez-Calero, El contrato de transporte marítimo de mercancías, 48 (Consejo Superior de Investigaciones Científicas, CSIC, Madrid, 1957). LuIs EduARdo ECHEVARríA-RIVERA, El transporte maritimo - enciclopedia sucinta de las ramas del derecho que lo regulan, 56 (Aranzadi, Pamplona, 1983). Paul Chauveau, Traité de droit maritime, 493 (Librairies Techniques, Paris, 1958). Juan Hernández-Martí, Contrato de transporte marítimo de mercancías, 31 (s.n., Valencia, 1984).

18 We understand the obligation as the various behaviors required of the carrier in order to obtain the result of the transfer of the goods. For example, the duty to make transport within a specified period, the obligation of keeping the goods, and delivery upon arrival under the terms agreed.

19 Similarly, in the air carriage of passengers, the carrier assumes a dual obligation: carry passengers from one place to another, within an agreed route and make the passenger transport without suffering any damage to the people or their luggage. The contract, thus, revolves around the obligation to transport. IGNACIO QuintANA-CARLO, La responsabilidad del transportista aéreo por daños a los pasajeros, 101 (Universidad de Salamanca, Salamanca, 1977). 
that "transportation is a contract whereby one party agrees to another, in exchange for a fee, to drive from one place to another, given medium and the deadline, people or things, and deliver them to the recipient."

Other provisions of the Code clearly reiterate the obligation of transportation as the property of the carrier. Then, section 982 of the Colombian Commercial Code provides that "the carrier shall be obliged... 1. In the carriage of goods to receiving, leading them and delivering them in the same conditions as received..." Article 1008 of the Colombian Commercial Code defines "carrier" as "a person who agrees to receive, conduct and deliver things subject of the contract..." Particularly, in regulating the contract of carriage of goods in general, Article 1600 of the Colombian Commercial Code established as the sea carrier obligation to proceed in the stipulated time or usual, appropriate and careful way to "upload, storage, preserve, transport, care, and discharge of the goods transported."

We must, however, interpret the rules of the Colombian Commercial Code as they relate to current international standards, in particular, the Hague-Visby Rules, Hamburg Rules and the Rotterdam Rules, as these regulations refer to the contracts and forms that are commonly used in the practice of international negotiation. In these cases, therefore, the interpreter will be obliged to give effect to these covenants understood in the light of our legal institutions that belong to the European continental family law.

\section{THE TRANSPORT OBLIGATION AS PRIME ISSUE IN THE CARRIAGE OF GOODS BY SEA CONTRACT UNDER THE COMPARATIVE LAW}

Under French law, the legislature has chosen to regulate the transport of maritime goods through a special law. ${ }^{20}$ Although, originally

20 The fact that the regulation of carriage of goods has been made in France by special laws, rather than reforms of the Commercial Code, or by enacting its own code of maritime law (Italian option), it seems to be explained by the discussion that was raised in the French doctrine regarding the independence of maritime law from private law. The idea of particularism maritime law exposed initially by Georges Ripert and deepened by Julien Bonnecase, as what we might call an intermediate solution, can make us understand this option. The regulation through a special law allows the legal norm - maritime legal law, being a particular rule, to formally maintain a relative independence from private law, but otherwise, denying complete autonomy. IGNACIO Arroyo-Martínez, Estudios de Derecho Marítimo, I, 63 (Bosch, Barcelona, 1985). 
the French Ordinance of 1681 understood the affreightment as a lease of vessel, current regulation of carriage of goods deemed it as a contract of carriage, at whose center is the obligation to transfer goods.

The law currently in force is law 66-420 of June 18, 1966, regulating the matter of chartering and transportation of goods by sea. Article 15 provides that the cargo owner promises to pay a certain freight and conveyor to drive or move specific goods from one port to another. ${ }^{21}$ We must add to this express reference that said law (Article 21) recognizes in this type of contract the existence of other benefits with a special legal treatment.

On the other hand, in British law the regulatory agency of carriage of goods is the charter (affreightment), ${ }^{22}$ under which a ship-owner, either directly or through an agent, commits to carry goods by sea or provide a ship for that purpose. The institution of the affreightment can be instrumentalized through two documentary forms: either using a charter party, in which the ship-owner agrees to make available to the charterer the full capacity of his vessel for a particular voyage or a specific period of time; or a bill of lading is used if the vessel is employed in a service line, regularly transporting goods from different carriers. ${ }^{23}$ Between these two assumptions, which, as we have already mentioned, correspond to different economic situations, what really interests us is the latest, because it is equivalent to the contract of affreightment enshrined in the Spanish Shipping Act 2014 and the carriage of goods by sea contract under a bill of lading governed by the Colombian Commercial Code. As it has happened in the continental law, the

21 Article 15: "Par le contrat de transport maritime, le chargeur s'engage à payer un fret déterminé et le transporteur à acheminer une marchandise déterminée, d'un port à un autre. Les dispositions du présent titre s'appliquent depuis la prise en charge jusqu’à la livraison."

22 John Wilson, Carriage of Goods by Sea, 3 (Pitman Publishing, London, 1993). Robert SAmuel Theodore Chorley, Otto Charles Giles \& Nicholas J. Gaskell, Shipping Law, 165 (Pitman, London, 1992). Thomas Gilbert Carver\& Raoul Colinvaux, Carver's Carriage by Sea, 37 (13 ${ }^{\text {rd }}$ ed., Stevens \& Sons, London, 1982). Thomas Edward Scrutton, Michael J. Mustill, Stewart Crauford Boyd \& Alan Abraham Mocatta, Scrutton on Charterparties and Bills of Lading, 1 (19 $9^{\text {th }}$ ed., Sir Alan Abraham Mocatta, Michael J. Mustill \& Stewart C. Boyd, eds. Sweet \& Maxwell, London, 1984).

23 Soumyadipta Chanda, A Comparison of Rights and Liabilities under a Charter Party and a Bill of Lading, 24 University of San Francisco Maritime Law Journal, 1, 65-82 (2012). Available at: http://papers.ssrn.com/sol3/papers.cfm?abstract_id=1919597 
contract using the form of bill of lading includes within its contents a purpose of transport as an essential element thereof.

As opposed to the particularism of the French doctrine, the Italian opted for autonomy of maritime law. ${ }^{24}$ Based on this autonomy, the rules governing the carriage of goods were integrated into the Code of Navigation, within a regulatory legal framework of the activities of sea and air transport. According to the rules for the carriage of goods (including Articles 419, 439, and 451) by virtue of the contract of carriage, the carrier is obligated to someone else to transfer or move from place to place a total or partial load, or a singular thing in a particular or undetermined craft. ${ }^{25}$ The obligation to transfer from one place to another is the essential feature that must be carried out by the carrier within the execution of the contract.

Finally, it is essential to mention the treatment of the Hamburg Rules 1978 and the Rotterdam Rules 2008. Clearly the international importance of these two legal instruments -even though the first one has not been ratified yet by Spain and Colombia and, the second one has not yet entered in force- is that they have a vocation to govern the matter in the future. Both regulations would also apply immediately when individuals are referred to them by use of the principle of private autonomy.

The United Nations Convention on the Carriage of Goods held in Hamburg in 1978, has ruled in Article 1, paragraph 6, recognizing that by this type of contract the carrier is committed against payment of freight, to carry goods by sea from one port to another.

Similarly, Article 1 of the Rotterdam Rules defines "transportation contract" as a contract whereby the carrier commits against payment of freight to carry goods from place to place and the Article 11 provides that "in the present Convention, and in accordance with the terms of the contract of carriage, the carrier shall trans-

24 The structure of the Codice della Navigazione as a code of the common law originated in the thesis of Antonio Scialoja, who enunciated the need for separation of maritime law from private law on the basis that the rules of maritime subjects have a common denominator, navigation, which gives them their own characteristics. Giongio RighetTi, Trattato di Diritto Marittimo, II, 1390 (Giuffrè, Milano, 1987). Ignacio Arroyo-Martínez, Estudios de Derecho Maritimo, I, 63 (Bosch, Barcelona, 1985).

25 Antonio Lefebvre D’Ovidio, Gabriele Pescatore \& Leopoldo Tullio, Manuale di Diritto della Navigazione, 463 (Giuffrè, Milano, 2011). Plinio MancA, International Maritime Law, 3 vols., II, 18 (European Transport Law, Antwerp, 1970). 
port the goods to the place of destination and deliver them to the recipient." ${ }^{26}$ It is evident the reference to the transport obligation as essential within the structure of the contract of carriage of goods in both conventions.

26 Juan Carlos Sáenz-García de Albizu, Las obligaciones del porteador hasta la entrega de las mercancías en destino, en Las Reglas de Rotterdam - la regulación del contrato de transporte internacional de mercancías por mar, 111-138 (Alberto EMPARAnZA, dir., Marcial Pons, Barcelona, Madrid, Buenos Aires, 2010). 


\section{CONCLUSIONS}

1. The regulation of the contract of carriage of goods has evolved from a system of absolute freedom of agreements towards a limitation of freedom of the parties to establishing any contractual clause to the content and to the carrier's liability.

2. A first part of this evolution is the codified rules promulgated in the field of European continental law and the rules belonging to the Common Law. Both regulations have paved the way for special laws that have limited the contractual intent, such as, among others, the American Harter Act of 1893, the Spanish Shipping Act 2014, and the 1966 French law 66-420, in charter and sea transport.

3. This process of regulatory reform has been inspired by the growing international need for a uniform law, fairer and more balanced between those involved in maritime activities. At an International level, this has been manifested in the holding of various international treaties such as the Brussels Convention of 1924, the Hamburg Rules of 1978, and the recently adopted Rotterdam Rules of 2008.

4. Spain ratified the Brussels Convention of 1924 and subsequently passed the Shipping Act 2014, but has not ratified the agreement amending protocols of February 23, 1968 and December 21, 1979. This regulatory overlap and conflicts have generated difficulties when applying current regulations, which must necessarily consider incorporating Shipping Act 2014 rules in a subsidiary role.

5. Potential conflicts of statutory interpretation in the Spanish case should be resolved by applying prevalently special legislation established in 2014 (The Shipping Act), which establishes an imperative frame for maritime carrier's liability in a framework of an international uniformity system, only when the contract is entitled in a bill of lading. In this sense, taking into account the strong Anglo-Saxon influence in the content of the Brussels Convention of 1924, the solutions given in the system of common law should be considered to interpret and apply the Spanish legislation. Other contracts not incorporated in a bill of lading are regulated by Shipping Act 2014 rules. 
6. Even though Colombia has not ratified any international agreement on the subject, it has incorporated recognized institutions regulated by the Brussels Convention of 1924 into the regulation of the Commercial Code. Therefore, the interpretation those other countries give to this legal instrument are relevant in the case of Colombia and also within the framework of international uniformity established by the frequent use of contractual forms that refer to these international standards.

7. Article 7 of the Colombian Commercial Code provides the possibility to apply in the Colombian legal framework treaties or conventions ratified by Colombia, including those relating to the carriage of goods; none of the rules established in Articles 1 to 6 of the Code are applicable.

8. Regarding the traditional discussion, specifically given by the Spanish law on the legal nature of affreightment and the regulatory contract of carriage of goods, the consideration that this contract incorporates a fundamental obligation of transport over other interpretations that refer to lease, seems to break through. The fundamental obligation of transportation would integrate the concept of carrying the goods to the place of destination and delivering them, as regulated by the Colombian Code of Commerce and internationally applicable instruments, or by future vocation of regulation of matter, as is the case of the Rotterdam Rules 2008. 


\section{BIBLIOGRAPHY}

\section{Books}

Arroyo-Martínez, Ignacio, Estudios de Derecho Marítimo, I (Bosch, Barcelona, 1985).

Bonnecase, Julien, Le particularisme du droit commercial maritime (Imprimerie Yves Cadoret, Bordeaux, 1921).

Brunetti, Antonio, Derecho marítimo privado (Bosch, Barcelona, 1950).

Carver, Thomas Gilbert \& Colinvaux, Raoul, Carver's Carriage by Sea $\left(13^{\text {rd }}\right.$ ed., Stevens \& Sons, London, 1982).

Chauveau, Paul, Traité de droit maritime (Librairies Techniques, Paris, 1958).

Chorley, Robert Samuel Theodore; Giles, Otto Charles \& Gaskell, Nicholas J., Shipping Law (Pitman, London, 1992).

EChEVARría-Rivera, Luis EduARdo, El transporte marítimo - enciclopedia sucinta de las ramas del derecho que lo regulan (Aranzadi, Pamplona, 1983).

FARIÑa-Guitián, Francisco, El transporte maritimo y sus sistemas de responsabilidad (Consejo Superior de Investigaciones Científicas, CSIC, Ministerio de Marina, Madrid, 1959).

Girón-Tena, José, El naviero: directrices actuales de su régimen jurídico (Universidad de Deusto, Bilbao, 1959).

Hernández-Martí, JuAn, Contrato de transporte marítimo de mercancías (s.n., Valencia, 1984).

Lefebvre D’Ovidio, Antonio; Pescatore, Gabriele \& Tullio, Leopoldo, Manuale di Diritto della Navigazione (Giuffrè, Milano, 2011).

MancA, Plinio, International Maritime Law, 3 vols. (European Transport Law, Antwerp, 1970).

Rafael Matilla-Alegre, Contrato de utilización del buque, Lecciones (Bosch, Barcelona, 1988).

Pardessus, Jean-Marie, Collection des lois maritimes antérieures au XVIII ${ }^{e}$ siècle (L'imprimerie royale, Paris, 1845). Available at: http://gallica.bnf.fr/ark:/12148/ bpt6k109656h.r=collection+des+lois+maritimes.langFR, http://gallica.bnf.fr/ ark:/12148/bpt6k109657w/f689.image

Quintana-Carlo, Ignacio, La responsabilidad del transportista aéreo por daños a los pasajeros (Universidad de Salamanca, Salamanca, 1977).

Righetti, Giongio, Trattato di Diritto Marittimo, II (Giuffrè, Milano, 1987).

Ripert, Georges, Droit Maritime (Librairie Arthur Rousseau et Compagnie Éditeurs, Paris, 1929).

Rubio, Jesús, El fletamento en el derecho español (Revista de Derecho Privado, Madrid, 1953).

Sánchez-Calero, Fernando, El contrato de transporte marítimo de mercancías, 28 
(Consejo Superior de Investigaciones Científicas, CSIC, Madrid, 1957).

Scrutton, Thomas Edward; Mustill, Michael J.; Boyd, Stewart Crauford \& Mocatta, Alan Abraham, Scrutton on Charterparties and Bills of Lading (19 ${ }^{\text {th }}$ ed., Sir Alan Abraham Mocatta, Michael J. Mustill \& Stewart C. Boyd, eds. Sweet \& Maxwell, London, 1984).

Wilson, John, Carriage of Goods by Sea (Pitman Publishing, London, 1993).

\section{Contributions in collective books}

Carvajal-Ramírez, Patricio Ignacio, La persistencia de recipere en su acepción de prometer y la desvinculación entre vis maior y la exception labeonis en época post-clasica: salvum recipere obligare y suscipere in fidem suam, en Studi in onore di Antonino Metro, 409-450 (Carmela Russo-Ruggeri, Giuffrè, Milano, 2009).

Gómez-Segade, José Antonio, Algunos problemas actuales del Derecho Mercantil, en Estudios en homenaje a Rodrigo Uría, 209-227 (Civitas, Madrid, 1978).

Illescas-Ortiz, Rafael, El derecho uniforme del comercio internacional: elementos de base, Estudios de Derecho Mercantil en homenaje al profesor Manuel Broseta-Pont, II, 1781-1800 (Tirant lo Blanch, Valencia, 1993).

Sáenz-García de Albizu, Juan Carlos, Las obligaciones del porteador hasta la entrega de las mercancías en destino, en Las Reglas de Rotterdam - la regulación del contrato de transporte internacional de mercancías por mar, 111-138 (ALBERTO EMPARANZA, dir., Marcial Pons, Barcelona, Madrid, Buenos Aires, 2010).

\section{Journals}

BonAsSies, PIERre, Le droit du transport maritime de conteneurs à l'orée du $21^{e}$ siècle, 699 Droit Maritime Français, 7-15 (2009).

Chanda, Soumyadipta, A Comparison of Rights and Liabilities under a Charter Party and a Bill of Lading, 24 University of San Francisco Maritime Law Journal, 1, 65-82 (2012). Available at: http://papers.ssrn.com/sol3/papers.cfm?abstract_id=1919597

Gondra-Romero, José María, La moderna “lex mercatoria” y la unificación del derecho del comercio internacional, 127 Revista de Derecho Mercantil, 7-38 (1973).

MÉnAger, LÉOn RoBert, “Naulum" et "Receptum rem salvam fore". Contribution à l'étude de la responsabilité contractuelle dans les transports maritimes en droit romain, 38 Revue Historique de Droit Français et Étranger, 4, 263-307, 385-411 (1960).

Menéndez-Menéndez, Aurelio, El derecho mercantil en el siglo XXI, 4 La Ley: Revista Jurídica Española de Doctrina, Jurisprudencia y Bibliografía, 1196-1203 (1990).

Peláez, Manuel, Los contratos de fletamento en el derecho histórico catalán, 2 Anuario de Derecho Marítimo, 93-133 (1982).

Polo-SÁnchez, Eduardo, Alcance de la responsabilidad del fletante y del porteador por falta de navegabilidad inicial del buque, Revista Jurídica de Cataluña, RJC, 867912 (Sept.-Dec., 1969). 
Schmitthoff, Clive M., The Unification of the Law of International Trade, The Journal of Business Law, 105-119 (1968).

\section{International treaties and conventions}

International Convention for the Unification of Certain Rules of Law relating to Bills of Lading (Hague Rules), and Protocol of Signature (Brussels, 25 August 1924) Brussels Convention of 1924. Available at: http://www.admiraltylawguide.com/ conven/haguerules1924.html

Protocol (SDR Protocol) amending the International Convention for the Unification of Certain Rules of Law relating to Bills of Lading of 25 August 1924 (The Hague Rules), as amended by the Protocol of 23 February 1968 (Visby Rules) (Brussels, 21 December 1979). Available at: http://www.admiraltylawguide.com/conven/ sdrprotocol1979.html

Protocol to Amend the International Convention for the Unification of Certain Rules of Law Relating to Bills of Lading (Visby Rules) (Brussels, 23 February 1968). Available at: http://www.admiraltylawguide.com/conven/visbyrules1968.html

The Hague-Visby Rules. Available at: http://www.admiraltylaw.com/statutes/hague.php

United Nations Commission on International Trade Law, UNCITRAL, United Nations Convention on Contracts for the International Carriage of Goods Wholly or Partly by Sea (New York, 2008) Rotterdam Rules. Available at: http://www. uncitral.org/uncitral/en/uncitral_texts/transport_goods/2008rotterdam_rules. html

United Nations Commission on International Trade Law, UNCITRAL, United Nations Convention on the Carriage of Goods by Sea (Hamburg, 1978) Hamburg Rules. Available at: http://www.uncitral.org/uncitral/en/uncitral_texts/transport_ goods/Hamburg_rules.html, http://daccess-dds-ny.un.org/doc/UNDOC/GEN/ N94/057/28/PDF/N9405728.pdf?OpenElement

\section{International normativity}

England, Shipping Act or Carriage of Goods by Sea Act 1971. Available at: http://www. legislation.gov.uk/ukpga/1971/19/contents

France, Commercial Code. Available at: http://www.legifrance.gouv.fr/Traductions/ en-English/Legifrance-translations

France, Carriage of Goods by Sea Act April 2, 1936, Loi du 2 avril 1936 relative aux transports des marchandises par mer. Available at: http://www.legifrance.gouv. fr/affichTexte.do?cidTexte=LEGITEXT000006070992 $\&$ dateTexte $=$

France, The Great Ordinance of Marine of August 1681, Grande ordonnance de la marine d'août 1681. Available at: http://gallica.bnf.fr//ark:/12148/bpt6k95955s

France, 66-420 Act of June 18, 1966, Loi 66-420 du 18 juin 1966 sur les contrats d'affrètement et de transport maritimes. Available at: http://www.legifrance. gouv.fr/affichTexte.do;jsessionid=4376BC8E267D2BAA67EDE3703F01A3AA. 
tpdjo10v_2?cidTexte=JORFTEXT000000692464\&dateTexte $=20101103$

Italy, Code of Navigation, Codice della Navigazione, Approvazione del testo definitivo del Codice della navigazione (042U0327) (GU n.93 del 18-4-1942). Available at: http:// www.normattiva.it/uri-res/N2Ls?urn:nir:stato:regio.decreto:1942-03-30;327

Spain, Book of the Consulate of the Sea (StANLEY S. JAdos, translat. and ed., University of Alabama Press, Tuscaloosa, Alabama, 1975). Available at: http://libro.uca. edu/consulate/consulate.htm

Spain, Commercial Code, Real decreto de 22 de agosto de 1885 por el que se publica el Código de Comercio, 289 Boletín Oficial del Estado, BOE, 16 de octubre de 1885. Available at: http://www.boe.es/buscar/act.php?id=BOE-A-1885-6627

Spain, Constitution, passed by the Cortes Generales in Plenary Meetings of the Congress of Deputies and the Senate Held on October 31, 1978; Ratified by Referendum of the Spanish People on December 7, 1978; Sanctioned by His Majesty the King before the Cortes Generales on December 27, 1978. Available at: http:// www.congreso.es/portal/page/portal/Congreso/Congreso/Hist_Normas/Norm/ const_espa_texto_ingles_0.pdf

Spain, Instrumento de Ratificación de 16 de noviembre de 1981, del Protocolo de 21 de diciembre de 1979, que modifica el Convenio Internacional para la unificación de ciertas reglas en materia de conocimientos de embarque de 25 de agosto de 1924 (Gaceta de Madrid, 31 de julio de 1930), enmendado por el Protocolo de 23 de febrero de 1968, 36 Boletín Oficial del Estado, BOE, 11 de febrero de 1984, 36743677. Available at: http://www.boe.es/diario_boe/txt.php?id=BOE-A-1984-3645

Spain, Ordinances or James I of Aragon: The Barcelona Maritime Code of 1258. Available at: http://www.admiraltylawguide.com/documents/barcelona1258.html

Spain, Ordinances of Bilbao, 1737, Ordenanzas de la Ilustre Universidad, y Casa de Contratación de la muy noble y muy leal Villa de Bilbao (insertos sus reales privilegios) aprobadas, y confirmadas por el Rey Felipe V, 2 de diciembre de 1737 (Oficina de la Viuda de Don Manuel Fernández, Madrid, 1769).

Spain, Shipping Law, Ley 14/2014, navegación marítima, 24 de julio de 2014, 180 Boletín Oficial del Estado, BOE, 25 de julio de 2014, 59193-59311. Available at: http:// www.boe.es/diario_boe/txt.php?id=BOE-A-2014-7877

United States, Harter Act (Carriage of Goods by Sea), February 13, 1893, ch. 105, 27 Stat. 445. Available at: https://www.mcgill.ca/files/maritimelaw/Harter_Act.pdf

\section{Colombian normativity}

Colombia, Decree 410 of 1971 (March 27), by which the Commercial Code is enacted Commercial Code. Available at: http://www.secretariasenado.gov.co/senado/ basedoc/codigo_comercio.html 


\section{Cases}

Hose of Lords, Maxine Footwear Co. Ltd. v. Canadian Government Merchant Marine (1959) AC 589.

House of Lords, Stag Line Ltd. v. Foscolo, Mango \& Co. Ltd. (1932), AC 328. 